PIWULANG: Jurnal Pendidikan Agama Islam, Vol. 3 No. 2 Maret 2021, 92-104

P-ISSN : 2622-5638. E-ISSN : 2622-5654

Homepage: http://e-journal.staima-alhikam.ac.id/index.php/piwulang

\title{
PENGARUH PENGGUNAAN MEDIA PEMBELAJARAN BERBASIS VISUAL TERHADAP PRESTASI BELAJAR MATA PELAJARAN AQIDAH AKHLAK SISWA DI MIN PUTUSSIBAU
}

\author{
Achmad Syarifudin \\ STIT Iqra' Kapuas Hulu - Indonesia \\ Email: achmadsyarifudin@stitiqra.ac.id
}

\begin{abstract}
This study aims to determine whether there is a significant effect of the use of visual-based learning media on the learning achievement of MIN Putussibau students' moral aqidah subjects in the 2016/2017 academic year. This research is a quantitative research. The method used in this research is the method of analysis of variance regression and t test analysis. The research subjects were 60 respondents, using random sampling technique. Collecting data using the observation method, interview method, questionnaire method, and documentation method to find information about respondents. Based on the questionnaire data obtained, the use of visual-based learning media is in the medium category with a mean value of 38.81. Learning achievement in the subject of aqidah morals is seen from the grades of report card. Based on the data obtained, the learning achievement in aqidah akhlak subject is in the medium category with a mean value of 77.08. Based on the data analysis, the results of F reg are 12.65983685, then this Freg is greater than F table (0.01): 7.08 and F table (0.05): 4.00. Meanwhile, from the hypothesis test using the t-test, it was obtained tcount $=3.37$, so this tcount was greater than t table $(0.05: 2.00)$ and $(0.01: 2.66)$. So it can be concluded that Ho is rejected and Ha is accepted. This means that there is a significant effect of the use of visual-based learning media on the learning achievement of students of MIN Putussibau moral aqidah subject.
\end{abstract}

\begin{abstract}
Abstrak
Penelitian ini bertujuan untuk mengetahui apakah ada pengaruh yang signifikan penggunaan media pembelajaran berbasis visual terhadap prestasi belajar mata pelajaran aqidah akhlak siswa MIN Putussibau-Kapuas Hulu. Penelitian ini merupakan penelitian kuantitatif. Metode yang digunakan dalam penelitian ini adalah metode analisis varian regresi dan analisis uji $t$. Subyek penelitian sebanyak 60 responden, menggunakan teknik random sampling. Pengumpulan data menggunakan metode observasi, metode interview, metode kuesioner, dan metode dokumentasi untuk mencari informasi mengenai responden. Berdasarkan data angket yang diperoleh penggunaan media pembelajaran berbasis visual termasuk kategori sedang dengan nilai mean 38,81. Prestasi belajar mata pelajaran aqidah akhlak dilihat dari nilai rapot. Berdasarkan data yang diperoleh, prestasi belajar mata pelajaran aqidah akhlak termasuk kategori sedang dengan nilai mean 77,08. Berdasarkan analisis data, diperoleh hasil $\mathrm{F}$ reg yaitu 12,65983685, maka Freg ini lebih besar dari Ftabel (0,01):7,08 dan Ftabel (0,05): 4,00. Sedangkan dari uji hipotesis dengan menggunakan uji t-test diperoleh thitung $=3,37$, maka thitung ini lebih besar dari ttabel $(0,05: 2,00)$ dan $(0,01: 2,66)$. Jadi dapat disimpulkan Ho ditolak dan Ha diterima. Ini berarti ada pengaruh yang signifikan penggunaan media pembelajaran berbasis visual terhadap prestasi belajar mata pelajaran aqidah akhlak siswa MIN Putussibau.
\end{abstract}

Kata kunci: penggunaan media, Media visual, prestasi belajar. 
PIWULANG: Jurnal Pendidikan Agama Islam, Vol. 3 No. 2 Maret 2021, 92-104

P-ISSN : 2622-5638. E-ISSN : 2622-5654

Homepage: http://e-journal.staima-alhikam.ac.id/index.php/piwulang

\section{A. Pendahuluan}

Pada hakikatnya proses belajar mengajar adalah proses komunikasi. Kegiatan belajar mengajar di kelas merupakan suatu dunia komunikasi tersendiri di mana guru atau dosen dan siswa/mahasiswanya bertukar pikiran untuk mengembangkan ide dan pengertian. Dalam komunikasi sering timbul dan terjadi penyimpangan- penyimpangan sehingga komunikasi tersebut tidak efektif dan efisien, antara lain disebabkan oleh adanya kecenderungan verbalisme, ketidaksiapan siswa/mahasiswa, kurangnya minat dan kegairahan, dan sebagainya. ${ }^{1}$ Salah satu usaha untuk mengatasi keadaan demikian ialah dengan penggunaan media pembelajaran secara terintegrasi dalam proses belajar mengajar,karena fungsi media dalam kegiatan tersebut di samping sebagai penyaji stimulus informasi, sikap, dan lain-lain, juga untuk meningkatkan keserasian dalam penerimaan informasi.

Proses belajar pada hakekatnya adalah proses komunikasi yaitu penyampaian pesan dari sumber pesan melalui saluran atau media tertentu ke penerima pesan. Pesan, sumber pesan, saluran atau media dan penerima pesan adalah komponen-komponen proses komunikasi. Pesan yang akan dikomunikasikan adalah isi ajaran atau didikan yang ada dalam kurikulum. Sumber pesannya bisa guru, siswa, orang lain ataupun penulis buku dan produser media. Salurannya adalah media pendidikan dan penerima pesannya adalah siswa atau juga guru.

Pada mulanya, media pembelajaran hanya berfungsi sebagai alat bantu visual dalam kegiatan pembelajaran, yaitu sebagai sarana untuk mendorong motivasi belajar siswa, memperjelas, dan mempermudah konsep yang abstrak dan mempertinggi daya serap. Kemudian dengan adanya pengaruh tehnologi, lahirlah berbagai alat peraga audiovisual yang menekankan pada penggunaan pengalaman yang konkret untuk menghindari verbalisme. ${ }^{2}$ Banyak media pembelajaran yang dapat digunakan dalam pembelajaran, salah satunya adalah media pembelajaran visual, dimana dengan media pembelajaran visual ini dapat membantu memudahkan siswa dalam memahami pelajaran. Media pembelajaran visual bisa dibuat guru dengan biaya murah, lain halnya media audio visual yang memerlukan peralatan dengan biaya mahal.

Levie \& Lentz mengemukakan fungsi media pengajaran, khususnya media visual, yaitu (a) fungsi atensi, (b) fungsi afektif, (c) fungsi kognitif,

\footnotetext{
${ }^{1}$ Basyiruddin M. Usman dan Asnawir, Media Pembelajaran, (Jakarta: Ciputat pers, 2002), hal.13.

2 Arief S. Sadiman, et. al., Media Pendidikan Pengertian, Pengembangan, dan Pemanfaatannya, (Jakarta: Raja Grafindo Persada, 2009), hal.13.
} 
PIWULANG: Jurnal Pendidikan Agama Islam, Vol. 3 No. 2 Maret 2021, 92-104

P-ISSN : 2622-5638. E-ISSN : 2622-5654

Homepage: http://e-journal.staima-alhikam.ac.id/index.php/piwulang

dan (d) fungsi kompensatoris. Fungsi atensi media visual merupakan inti, yaitu menarik dan mengarahkan perhatian siswa untuk berkonsentrasi kepada isi pelajaran yang berkaitan dengan makna visual yang ditampilkan atau menyertai teks materi pelajaran. Fungsi afektif media visual dapat terlihat dari tingkat kenikmatan siswa ketika belajar (atau membaca) teks yang bergambar. Gambar atau lambang visual dapat menggugah emosi dan sikap siswa, misalnya informasi yang menyangkut masalah sosial atau ras. ${ }^{3}$ Fungsi kognitif visual terlihat dari temuan-temuan penelitian yang mengungkapkan bahwa lambang visual atau gambar memperlancar pencapaian untuk memahami dan mengingat informasi atau pesan yang terkandung dalam gambar, sedangkan fungsi kompensatoris bahwa media visual yang memberikan konteks untuk memahami teks membantu siswa yang lemah dalam membaca untuk mengorganisasikan informasi dalam teks dan mengingatnya kembali. ${ }^{4}$

Aqidah akhlak di Madrasah Ibtidaiyah merupakan salah satu mata pelajaran PAI yang mempelajari tentang rukun iman yang dikaitkan dengan pengenalan dan penghayatan terhadap al-asma' alhusna, serta penciptaan suasana keteladanan dan pembiasaan dalam mengamalkan akhlak terpuji dan adab islami melalui pemberian contohcontoh perilaku dan cara mengamalkannya dalam kehidupan sehari-hari. Secara substansial mata pelajaran aqidah akhlak memiliki kontribusi dalam memberikan motivasi kepada peserta didik untuk mempraktikkan al- akhlakul karimah dan adab Islami dalam kehidupan sehari-hari sebagai manifestasi dari keimanan kepada Allah SWT. Mata pelajaran aqidah akhlak bertujuan untuk menumbuhkan dan meningkatkan keimanan peserta didik yang diwujudkan dalam akhlaknya yang terpuji, melalui pemberian dan pemupukan pengetahuan, penghayatan, pengamalan serta pengalaman peserta didik tentang aqidah akhlak Islam.

Pada umumnya peserta didik di Madrasah Ibtidaiyah berusia 7-11 tahun. Pada rentang usia ini perkembangan kognitif pada tahap konkret operasional. Anak-anak dalam rentang usia 7-11 tahun baru mampu berpikir sistematis mengenai benda-benda dan peristiwa-peristiwa konkret. ${ }^{5}$ Untuk itu diperlukan media pembelajaran khususnya media berbasis visual. Melalui media ini materi yang abstrak bisa dikonkretkan, juga dapat menarik perhatian peserta didik. Media pembelajaran berbasis visual digunakan dalam proses belajar mengajar di

\footnotetext{
3 Azhar Arsyad, Media Pembelajaran, (Jakarta: PT RajaGrafindo Persada, 2003), Cet. V, hal.16.

${ }^{4}$ Azhar Arsyad, Media Pembelajaran..., hal.17.

5 Muhibbin Syah, Psikologi Pendidikan dengan Pendekatan Baru, (Bandung: PT Remaja Rosdakarya, 2008), Cet. XIV, hal.73.
} 
PIWULANG: Jurnal Pendidikan Agama Islam, Vol. 3 No. 2 Maret 2021, 92-104

P-ISSN : 2622-5638. E-ISSN : 2622-5654

Homepage: http://e-journal.staima-alhikam.ac.id/index.php/piwulang

MIN Putussibau dengan tujuan menarik perhatian siswa dan mengkongkretkan materi pelajaran yang bersifat abstrak. Demikian pula materi mata pelajaran aqidah akhlak yang bersifat abstrak, maka dibutuhkan media berbasis visual. Maka fokus artikel ini ingin melihat pengaruh penggunaan media pembelajaran berbasis visual terhadap prestasi belajar mata pelajaran aqidah akhlak, dengan pokok permasalahan yang hendak dibahas yaitu; Apakah ada pengaruh yang signifikan dari penggunaan media pembelajaran berbasis visual terhadap prestasi belajar mata pelajaran aqidah akhlak siswa MIN Putussibau.

\section{B. Metode}

Metode yang digunakan dalam penelitian ini adalah kuantitatif dengan sampel sebanyak 60 siswa. Teknik pengambilan sampel dengan menggunakan probability sampling, yaitu memberikan peluang yang sama bagi setiap anggota sampel. Metode pengumpulan data dilakukan dengan menggunakan angket (kuisioner) dan didukung dengan wawancara dan dokumentasi sebagai pelengkap. Analisis data penelitian ini dengan menggunakan uji signifikansi persamaan regresi untuk mengetahui adanya pengaruh penggunaan media visual terhadap prestasi belajar siswa.

\section{Hasil}

Data hasil angket tentang penggunaan media pembelajaran berbasis visual (variabel X). Diskripsi data tentang penggunaan media pembelajaran berbasis visual diperoleh dari hasil angket yang diberikan kepada siswa sebagai responden yang berjumlah 60 siswa. Peneliti menentukan nilai kuantitatif tentang penggunaan media pembelajaran berbasis visual dengan menjumlah skor jawaban angket dari responden.

Berdasarkan tabel kategori nilai, dapat diketahui bahwa prestasi belajar mata pelajaran aqidah akhlak siswa MIN Putussibau termasuk kategori sedang yaitu dengan mean 77,08.

Dengan membandingkan rata-rata nilai sebelum penelitian $(74,4)$ dan rata-rata nilai rapot mata pelajaran aqidah akhlak $(77,0833)$ dapat disimpulkan bahwa ada peningkatan prestasi belajar mata pelajaran aqidah akhlak karena penggunaan media berbasis visual.

Berdasarkan pengolahan data, hasil Freg ini digunakan untuk menguji hipotesis yang telah ada (signifikansi regresi kriterium Y terhadap prediktor X). Berdasarkan perhitungan diketahui Freg adalah 12,65 maka Freg lebih besar dari Ftabel (0,01: 7,08 dan Ftabel $(0,05): 4,00$, maka berarti ada pengaruh yang signifikan penggunaan media berbasis visual terhadap prestasi belajar aqidah akhlak siswa MIN Putussibau. 
PIWULANG: Jurnal Pendidikan Agama Islam, Vol. 3 No. 2 Maret 2021, 92-104

P-ISSN : 2622-5638. E-ISSN : 2622-5654

Homepage: http://e-journal.staima-alhikam.ac.id/index.php/piwulang

Berdasarkan pengolahan data, hasil perhitungan $t$ adalah 3,37. apabila thitung $>$ ttabel berarti rumusan hipotesis tidak ada pengaruh yang signifikan penggunaan media berbasis visual terhadap prestasi belajar mata pelajaran aqidah akhlak $\left(\mathrm{H}_{\mathrm{O}}\right)$ ditolak, sebaliknya rumusan hipotesis ada pengaruh yang signifikan penggunaan media berbasis visual terhadap prestasi belajar mata pelajaran aqidah akhlak (Ha) diterima.

\section{Pembahasan}

\section{Makna Media}

Media merupakan sesuatu yang bersifat menyalurkan pesan dan dapat merangsang pikiran, perasaan dan kemauan audien (siswa) sehingga dapat mendorong terjadinya proses belajar mengajar. Salah satu pengertian media adalah yang diungkapkan oleh Gerbich dan Ely, media secara garis besar adalah materi atau kejadian yang membangun kondisi yang membuat siswa mampu memperoleh pengetahuan, keterampilan dan sikap. Secara khusus media dalam proses belajar mengajar dapat diartikan sebagai alat grafis, photography atau elektronik untuk menangkap, memproses dan menyusun kembali informasi visual atau verbal.

Gagne dan Briggs mengatakan bahwa media pembelajaran meliputi alat yang secara fisik digunakan untuk menyampaikan isi materi pengajaran, yang terdiri dari antara lain buku, tape-recorder, kaset, video kamera, film, foto, gambar, grafik, televisi, dan komputer. Media pembelajaran adalah sarana komunikasi yang digunakan untuk menyampaikan pesan atau bahan pembelajaran. ${ }^{6}$

Media pembelajaran dilihat dari jenisnya, dapat diklasifikasikan menjadi media audio, media cetak, dan media elektronik. Ada beberapa jenis media pendidikan yang biasa digunakan dalam proses pengajaran; media grafis, media tiga dimensi, media proyeksi seperti slide, filmstrip, film, dan penggunaan OHP.

Menurut Gerlach dan Ely yang dikutip oleh Azhar Arsyad mengemukakan 3 ciri media yang merupakan petunjuk mengapa media digunakan dan apa saja yang dapat dilakukan oleh media yang mungkin guru tidak mampu atau kurang efisien melakukannya. Ciri-ciri media tersebut antara lain: Ciri fiksatif (fixative property) yang menggambarkan kemampuan media merekam, menyimpan, melestarikan dan merekonstruksi suatu peristiwa atau objek. Dengan

\footnotetext{
${ }^{6}$ Bambang Warsita, Teknologi Pembelajaran Landasan dan aplikasinya, (Jakarta: Rineka Cipta, 2008), Cet. 1, hal.121.
} 
PIWULANG: Jurnal Pendidikan Agama Islam, Vol. 3 No. 2 Maret 2021, 92-104

P-ISSN : 2622-5638. E-ISSN : 2622-5654

Homepage: http://e-journal.staima-alhikam.ac.id/index.php/piwulang

ciri fiksatif ini, media memungkinkan suatu rekamankejadian atau objek yang terjadi pada satu waktu tertentu ditransportasikan tanpa mengenal waktu; Ciri manipulatif (manipulative property) merupakan transformasi suatu kejadian atau objek dimungkinkan karena media memiliki ciri manipulatif. Kejadian yang memakan waktu berhari-hari dapat disajikan kepada siswa dalam waktu dua atau tiga menit dengan teknik pengambilan gambar. Misalnya bagaimana proses perubahan larva menjadi kupu-kupu dapat dipercepat dengan teknik rekaman fotografi; ciri distributif (distributive property) dari media memungkinkan suatu objek atau kejadian ditransportasikan melalui ruang, dan secara bersamaan kejadian tersebut disajikan kepada sejumlah besar siswa dengan stimulus pengalaman yang relatif sama dengan kejadian itu.

\section{Media Pembelajaran Berbasis Visual}

Media pembelajaran visual (image atau perumpamaan) memegang peran yang sangat penting dalam proses belajar. Media visual dapat memperlancar pemahaman (misalnya melalui elaborasi struktur dan organisasi) dan memperkuat ingatan. Visual dapat pula menumbuhkan minat siswa dan dapat memberikan hubungan antara isi materi pelajaran dengan dunia nyata. Agar menjadi efektif, visual sebaiknya ditempatkan pada konteks yang bermakna dan siswa harus berinteraksi dengan visual itu untuk meyakinkan terjadinya proses informasi. Visualisasi pesan, informasi, atau konsep yang ingin disampaikan kepada siswa dapat dikembangkan dalam berbagai bentuk, seperti foto, gambar/ilustrasi, sketsa/gambar garis, grafik, bagan, chart, dan gabungan dari dua bentuk atau lebih. Foto menghadirkan ilustrasi melalui gambar yang hampir menyamai kenyataan dari sesuatu obyek atau situasi. Sementara itu, grafik merupakan representasi simbolis dan artistik sesuatu obyek atau situasi.

Keberhasilan penggunaan media berbasis visual ditentukan oleh kualitas dan efektivitas bahan-bahan visual dan grafik itu. Hal ini hanya dapat dicapai dengan mengatur dan mengorganisasikan gagasan-gagasan yang timbul, merencanakannya dengan seksama, dan menggunakan teknik-teknik dasar visualisasi obyek, konsep, informasi, atau situasi. Bentuk visual bisa berupa; gambar representasi, diagram, peta, grafik dan chart. ${ }^{7}$

${ }^{7}$ Azhar Arsyad, Media Pembelajaran..., hal.89. 
PIWULANG: Jurnal Pendidikan Agama Islam, Vol. 3 No. 2 Maret 2021, 92-104

P-ISSN : 2622-5638. E-ISSN : 2622-5654

Homepage: http://e-journal.staima-alhikam.ac.id/index.php/piwulang

\section{Prestasi Belajar}

Menurut M. Ngalim Purwanto belajar adalah suatu perubahan yang terjadi melalui latihan atau pengalaman, dalam arti perubahanperubahan yang disebabkan oleh pertumbuhan atau kematangan tidak dianggap sebagai hasil belajar, seperti perubahan- perubahan yang terjadi pada diri seorang bayi. ${ }^{8}$ Secara umum belajar merupakan suatu proses pengalaman dan latihan akibat interaksi individu dengan lingkungan sehingga menghasilkan perubahan perilaku yang mencakup pengetahuan, pemahaman, keterampilan, sikap dan kemampuannya di bidang tertentu. Belajar bagi manusia merupakan keharusan yang mesti dijalankan karena dengan belajar ilmu pengetahuan dan jendela wawasan dunia dapat terlihat.

Perubahan tingkah laku sebagai hasil belajar ialah perubahan yang dihasilkan dari pengalaman (interaksi dengan lingkungan), di mana proses mental dan emosional terjadi. Menurut Benjamin S. Bloom ada tiga ranah hasil belajar yaitu kognitif, afektif dan psikomotorik.

\section{Perubahan Ranah Hasil Belajar a) Ranah kognitif}

Dalam taksonomi revisi Aplikasi, Analisis, dan Evaluasi dipertahankan, tetapi dalam bentuk kata kerja sebagai Menerapkan, Menganalisis, dan Mengevaluasi. Sintesis berubah tempat dengan Evaluasi dan berganti nama Mencipta. ${ }^{9}$ Komponen kata kerja dari Pengetahuan berubah menjadi kategori mengingat, yang menggantikan klasifikasi pengetahuan aslinya dalam enam kategori pokok, yang sekarang menggunakan kata kerja. Bentuk kata kerja ini mendeskripsikan tindakan yang tersirat dalam kategori pengetahuan aslinya; tindakan pertama yang dilakukan siswa dalam belajar pengetahuan adalah mengingatnya.

Urutan taksonomi yang mengalami perubahan adalah letak evaluasi dan sintesa serta penggantian nama komprehensi menjadi memahami dan sintesa menjadi mencipta. Perubahan urutan kategori-kategori dalam taksonomi Bloom didasari oleh kerangka berpikir revisi adalah hierarki dalam pengertian bahwa enam

\footnotetext{
${ }^{8}$ M. Ngalim Purwanto, Psikologi Pendidikan, (Bandung: Remaja Rosdakarya, 1990), Cet. 5, hal. 84.

${ }^{9}$ Krathwohl, David R. 2002. "A Revision of Bloom's Taxonomy: An Overview", Theory Into Practice, Volume 41, Number 4, Autum 2002. Ohio: College of Education, The Ohio State University.
} 
kategori pokok pada dimensi proses kognitif disusun secara berurutan dari tingkat kompleksitas yang rendah ke tinggi.

Jumlah dan jenis proses kognitif tetap sama seperti dalam taksonomi yang lama, hanya kategori analisis dan evaluasi ditukar urutannya dan kategori sintesis kini dinamai membuat (create). Seperti halnya taksonomi yang lama, taksonomi yang baru secara umum juga menunjukkan penjenjangan, dari proses kognitif yang sederhana ke proses kognitif yang lebih kompleks. Namun demikian penjenjangan pada taksonomi yang baru lebih fleksibel sifatnya. Artinya, untuk dapat melakukan proses kognitif yang lebih tinggi tidak mutlak disyaratkan penguasaan proses kognitif yang lebih rendah. Berikut ini merupakan perbedaan piramida taksonomi bloom sebelum revisi dan sesudah revisi.

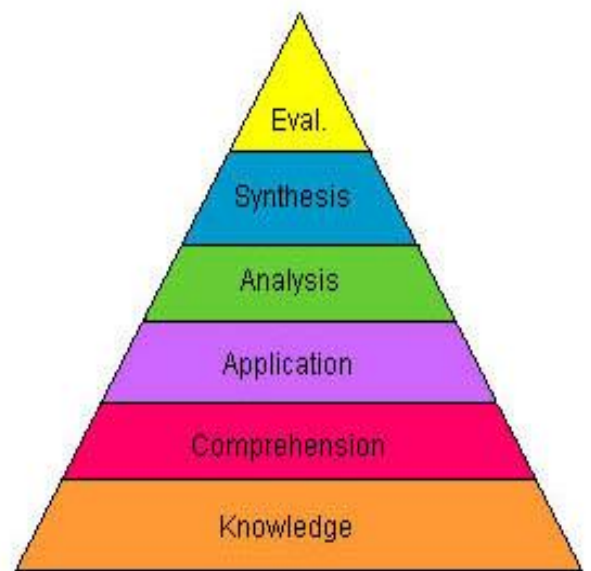

Old Version

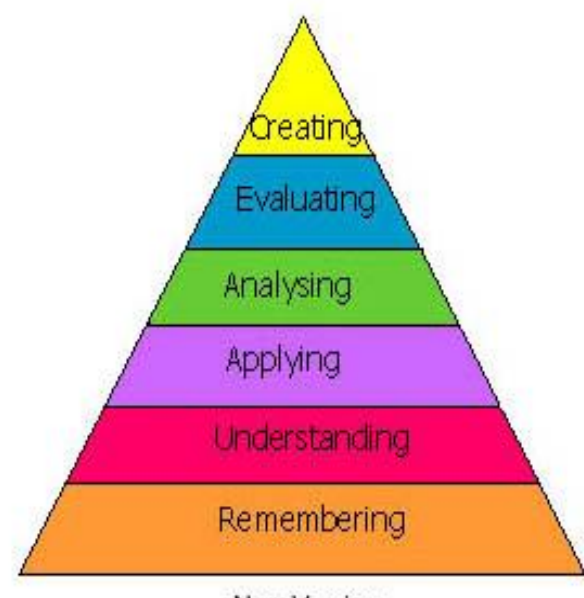

New Version

1) Menghafal (Remembering). Menarik kembali informasi yang tersimpan dalam memori jangka panjang. Mengingat merupakan proses kognitif yang paling rendah tingkatannya. Untuk mengkondisikan agar "mengingat" bisa menjadi bagian belajar bermakna, tugas mengingat hendaknya selalu dikaitkan dengan aspek pengetahuan yang lebih luas dan bukan sebagai suatu yang lepas dan terisolasi. Kategori ini mencakup dua macam proses kognitif: mengenali (recognizing) dan mengingat (recalling).

2) Memahami (Understand): Mengkonstruk makna atau pengertian berdasarkan pengetahuan awal yang dimiliki, mengaitkan informasi yang baru dengan pengetahuan yang telah dimiliki, atau mengintegrasikan pengetahuan yang baru ke dalam skema yang telah ada dalam pemikiran siswa. Karena penyususn skema adalah konsep, maka pengetahuan konseptual merupakan dasar pemahaman. Kategori memahami mencakup tujuh proses 
PIWULANG: Jurnal Pendidikan Agama Islam, Vol. 3 No. 2 Maret 2021, 92-104

P-ISSN : 2622-5638. E-ISSN : 2622-5654

Homepage: http://e-journal.staima-alhikam.ac.id/index.php/piwulang

kognitif: menafsirkan (interpreting), memberikan contoh (exemplifying), mengkelasifikasikan (classifying), meringkas (summarizing), menarik inferensi (inferring), membandingkan (comparing), dan menjelaskan (explaining).

3) Mengaplikasikan (Applying). Mencakup penggunaan suatu prosedur guna menyelesaikan masalah atau mengerjakan tugas. Oleh karena itu mengaplikasikan berkaitan erat dengan pengetahuan prosedural. Namun tidak berarti bahwa kategori ini hanya sesuai untuk pengetahuan prosedural saja. Kategori ini mencakup dua macam proses kognitif: menjalankan (executing) dan mengimplementasikan (implementing).

4) Menganalisis (Analyzing) Menguraikan suatu permasalahan atau obyek ke unsurunsurnya dan menentukan bagaimana saling keterkaitan antar unsur-unsur tersebut dan struktur besarnya. Ada tiga macam proses kognitif yang tercakup dalam menganalisis: membedakan (differentiating), mengorganisir (organizing), dan menemukan pesan tersirat (attributting).

5) Mengevaluasi (Evaluating) adalah Membuat suatu pertimbangan berdasarkan kriteria dan standar yang ada. Ada dua macam proses kognitif yang tercakup dalam kategori ini: memeriksa (checking) dan mengritik (critiquing).

6) Mencipta (create) adalah Menggabungkan beberapa unsur menjadi suatu bentuk kesatuan. Ada tiga macam proses kognitif yang tergolong dalam kategori ini, yaitu: membuat (generating), merencanakan (planning), dan memproduksi (producing).

\section{b) Ranah Afektif}

Ranah afektif merupakan ranah yang berkaitan aspek -aspek emosional, seperti perasaan, minat, sikap, kepatuhan terhadap moral dan sebagainya, di dalamnya mencakup: penerimaan (receiving), sambutan (responding), penilaian (valuing), pengorganisasian (organization), dan karakterisasi (characterization).

1) Menerima. Mencakup kepekaan akan adanya suatu perangsang dan kesediaan untuk memperhatikan rangsangan itu, seperti buku pelajaran atau penjelasan yang diberikan oleh guru. Kesediaan itu dinyatakan dalam memperhatikan sesuatu, seperti memandangi gambar yang dibuat di papan tulis atau mendengarkan jawaban teman sekelas atas pertanyaan guru. Dipandang dari segi pengajaran jenjang ini berhubung dengan menimbulkan, 
PIWULANG: Jurnal Pendidikan Agama Islam, Vol. 3 No. 2 Maret 2021, 92-104

P-ISSN : 2622-5638. E-ISSN : 2622-5654

Homepage: http://e-journal.staima-alhikam.ac.id/index.php/piwulang

mempertahankan dan mengarahkan perhatian siswa. Hasil belajarnya bahwa sesuatu itu ada sampai kepada minat khusus dari pihak siswa.

2) Menjawab. Kemampuan ini bertalian dengan partisipasi siswa. Pada tingkat ini, siswa tidak hanya menghadiri suatu fenomena tertentu tetapi juga mereaksi terhadapnya dengan salah satu cara. Hasil belajar jenjang ini dapat menekankan kemauan untuk menjawab atau kepuasan dalam menjawab.

3) Menilai. Mencakup kemampuan untuk memberikan penilaian terhadap sesuatu untuk membawa diri sesuai dengan penilaian itu. Mulai dibentuk suatu sikap: menerima, menolak, atau mengabaikan,sikap itu dinyatakan dalam tingkah laku yang sesuai dan konsisten dengan sikap batin. Kemampuan itu dinyatakan dalam suatu perkataan atau tindakan. perkataan atau tindakan itu tidak hanya sekali saja tetapi diulang kembali bila kesempatannya timbul, dengan demikian nampaklah adanya suatu sikap tertentu.

4) Organisasi. Tingkat ini berhubungan dengan menyatukan nilai-nilai yang berbeda, menyelesaikan/ memecahkan konflik di antara nilai-nilai itu, dan mulai membentuk suatu sistem nilai yang konsisten secara internal. Jadi, memberikan penekanan pada membandingkan, menghubungkan dan mensintesiskan nilai-nilai.

5) Karakter. Hasil belajar bertalian dengan konseptualisasi suatu nilai (mengakui tanggung jawab tiap individu untuk memperbaiki hubungan-hubungan manusia) atau dengan organisasi suatu sistem nilai (merencanakan suatu pekerjaan untuk memenuhi kebutuhannya baik dalam hal keamanan ekonomi maupun pelayanan sosial. ${ }^{10}$

Ranah afektif adalah ranah yang berkaitan dengan sikap dan nilai. Ranah afektif mencakup watak perilaku seperti perasaan, minat, sikap, emosi, dan nilai. Ciri-ciri hasil belajar afektif akan tampak pada peserta didik dalam berbagai tingkah laku. Seperti: perhatiannnya terhadap mata pelajaran pendidikan agama Islam, kedisiplinannya dalam mengikuti mata pelajaran

${ }^{10}$ H. Daryanto, Evaluasi Pendidikan, (Jakarta: Rineka Cipta, 2008), hal. 117-118 
PIWULANG: Jurnal Pendidikan Agama Islam, Vol. 3 No. 2 Maret 2021, 92-104

P-ISSN : 2622-5638. E-ISSN : 2622-5654 Homepage: http://e-journal.staima-alhikam.ac.id/index.php/piwulang agama disekolah, motivasinya yang tinggi untuk tahu lebih banyak mengenai pelajaran agama Islam yang di terimanya, penghargaan atau rasa hormatnya terhadap guru pendidikan agama Islam dan sebagainya.

\section{c) Ranah Psikomotorik}

Ranah Psikomotor adalah ranah yang berkaitan dengan ketrampilan (skill) atau kemampuan bertindak setelah seseorang menerima pengalaman belajar. Ranah psikomotor dapat dikelompokkan dalam tiga kelompok utama, yakni ketrampilan motorik, manipulasi benda-benda, dan koordinasi neuromuscular. Kata-kata kerja operasional yang dapat dipakai adalah; Keterampilan motorik (muscular or motor skillls), memperlihatkan gerak, menunjukkan hasil (pekerjaan tangan), menggerakkan, menampilkan, melompat, dan sebagainya; Manipulasi benda-benda (manipulation of materials or object): menyusun, membentuk, memindahkan, menggeser, mereparasi, dan sebagainya; Koordinasi neuromuscular, menghubungkan, mengamati, dan memotong.

\section{Mata Pelajaran Aqidah Akhlak}

Secara substansial mata pelajaran Aqidah Akhlak memiliki kontribusi dalam memberikan motivasi kepada peserta didik untuk mempraktekkan nilai-nilai keyakinan keagamaan (tauhid) dan akhlaqul karimah dalam kehidupan sehari- hari, meningkatkan keimanan peserta didik yang diwujudkan dalam akhlaknya yang terpuji, melalui pemberian dan pemupukan pengetahuan, penghayatan, pengalaman peserta didik tentang aqidah dan akhlak Islam.

Mata pelajaran Aqidah Akhlak di madrasah memiliki fungsi sebagai berikut: penanaman nilai dan ajaran Islam sebagai pedoman mencapai kebahagiaan hidup dunia akhirat; peneguhan keimanan dan ketaqwaan kepada Allah SWT, serta pengembangan akhlak mulia peserta didik seoptimal mungkin, melanjutkan pendidikan yang telah dahulu dilaksanakan dalam keluarga; penyesuaian diri peserta didik terhadap lingkungan fisik dan sosial dengan bekal aqidah akhlak; perbaikan masalah-masalah, kelemahan-kelemahan peserta didik dalam keyakinan, pengamalan ajaran agama Islam dalam kehidupan sehari-hari; pencegahan peserta didik dari hal-hal negatif dari lingkungannya atau dari budaya asing yang dihadapi sehari-hari; pengajaran tentang informasi dan pengetahuan keimanan dan akhlak, 
PIWULANG: Jurnal Pendidikan Agama Islam, Vol. 3 No. 2 Maret 2021, 92-104

P-ISSN : 2622-5638. E-ISSN : 2622-5654

Homepage: http://e-journal.staima-alhikam.ac.id/index.php/piwulang

serta sistem fungsionalnya; pembekalan peserta didik untuk mendalami aqidah akhlak pada jenjang yang lebih tinggi.

\section{E. Kesimpulan}

Perolehan data tentang Penggunaan media pembelajaran berbasis visual diperoleh dengan metode kuesioner (angket) dengan jumlah responden 60. Berdasarkan analisis data yang diperoleh, disimpulkan bahwa media pembelajaran berbasis visual digunakan dalam proses belajar mengajar di MIN Putussibau. Hal ini dibuktikan dengan masuknya nilai mean dalam kategori sedang yaitu; 38,81667.

Data prestasi belajar mata pelajaran aqidah akhlak diperoleh dengan metode observasi nilai rapot semester 2 siswa MIN Putussibau tahun pelajaran 2016/2017. Berdasarkan analisis data yang diperoleh, prestasi belajar mata pelajaran aqidah akhlak masuk dalam kategori sedang, yang dibuktikan dengan nilai mean 77,0833.

Berdasarkan data-data yang terkumpul dan telah dianalisis maka kesimpulan yang dapat diambil adalah ada pengaruh yang signifikan penggunaan media berbasis visual terhadap prestasi belajar mata pelajaran aqidah akhlak siswa MIN Putussibau di tahun pelajaran 2016/2017. Hal dibuktikan dengan hasil perhitungan Freg $=12,65983685$ yang lebih besar dari Ftabel (0,01:7,08 dan Ftabel (0,05): 4,00. Uji signifikansi hipotesis dengan uji t-test. Berdasarkan data- data yang telah dianalisis diperoleh thitung $=3,37$. Setelah melihat tabel $\mathrm{t}$ dengan $\mathrm{n}=60$ diperoleh 2,00 untuk taraf kesalahan 5\% dan 2,66 untuk taraf kesalahan $1 \%$, maka thitung $>$ tabel berarti rumusan hipotesis tidak ada pengaruh yang signifikan penggunaan media berbasis visual terhadap prestasi belajar mata pelajaran aqidah akhlak (Ho) ditolak sebaliknya rumusan hipotesis ada pengaruh yang signifikan penggunaan media berbasis visual.

\section{Daftar Pustaka}

Abdul Kholiq, Analisis Kurikulum Madrasah Mata Pelajaran Akidah Akhlak, Semarang : Kementerian Agama RI Fakultas Tarbiyah IAIN Walisongo, 2010 .

Arikunto, Suharsimi. Prosedur Penelitian Suatu Pendekatan Praktek, Jakarta: PT. Rineka Cipta, 2002, Cet. XI. 
PIWULANG: Jurnal Pendidikan Agama Islam, Vol. 3 No. 2 Maret 2021, 92-104

P-ISSN : 2622-5638. E-ISSN : 2622-5654

Homepage: http://e-journal.staima-alhikam.ac.id/index.php/piwulang

Arsyad, Azhar. Media Pembelajaran, Jakarta : PT RajaGrafindo Persada, 2003, Cet. V.

Asnawir dan Usman, M. Basyirudin, Media Pembelajaran, Jakarta: Ciputat Pers, 2002

Basyiruddin Usman, Metodologi Pembelajaran Agama Islam, Jakarta: Ciputat Pers, 2002, Cet. 1.

Daryanto, H. Evaluasi Pendidikan, Jakarta: Rineka Cipta, 2008.

Direktorat Pendidikan pada Madrasah, Standar Isi Madrasah Ibtidaiyah, Jakarta: Direktorat Jenderal kelembagaan Agama Islam Departemen Agama RI, 2006.

Hadi, Sutrisno. metodologi Research jilid 2, Yogyakarta: Andi, 2004.

Hamruni, Strategi dan Model-model Pembelajaran Aktif Menyenangkan, Yogyakarta: Fakultas Tarbiyah UIN Sunan Kalijaga, 2009.

Harjanto, Perencanaan Pengajaran., Jakarta : Rineka Cipta, 2003, cet. 3.

Hartono, Statistik untuk Penelitian,Yogyakarta: Pustaka Pelajar, 2008.

Ismail SM, Strategi Pembelajaran Agama Islam Berbasis PAIKEM, Semarang : RaSail Group, 2008, Cet. 1

M. Usman Basyiruddin dan Asnawir, Media Pembelajaran Jakarta: Ciputat pers, 2002, Cet.1.

Mukhtar, Desain Pembelajaran Pendidikan Agama Islam, Jakarta: CV. Misaka Galiza, 2003, Cet. I.

Purwanto. M. Ngalim, Psikologi Pendidikan, Bandung: Remaja Rosdakarya, 1990), Cet. 5.

Sadiman. Arief S., et. al., Media Pendidikan Pengertian, Pengembangan, dan Pemanfaatannya, Jakarta: RajaGrafindo Persada, 2009.

Sekretaris Negara Republik Indonesia, Undang-undang Sistem Pendidikan Nasional, Yogyakarta: Pustaka Pelajar, 2007.

Sugiyono, Anas, Pengantar Evaluasi Pendidikan, Jakarta: Rajawali Pers, 2009.

Syah. Muhibbin, Psikologi Pendidikan dengan Pendekatan Baru, Bandung : PT Remaja Rosdakarya, 2008, Cet. XIV.

Warsita. Bambang, Tehnologi Pembelajaran Landasan dan Aplikasinya, Jakarta: Rineka Cipta, 2008, Cet. 1. 